\title{
PENGARUH KEPEMIMPINAN DAN MOTIVASI KERJA TERHADAP PRESTASI KERJA KARYAWAN UNIVERSITAS LANCANG KUNING PEKANBARU
}

\author{
Musfawati \\ Universitas Lancang Kuning \\ e-mail: musfawati@unilak.ac.id
}

\begin{abstract}
This study aims to analyze and examine the influence of leadership and motivation of the university employee work preformance Lancang Kuning Pekanbaru. Research Methodology used is descriptive quantitative, while the population in this study are university employees who Lancang Kuning numbered 70 people. The Sampling Technique Is Stratifed Proportional Random Sampling. To determine the relationship and the influence of an independent variable to the model variables are bound to use Multiple Linear Regression Analysis. While to test the hypothesis using statistical tests. Research results show that the calculation statistically obtained Multiple Correlation Coefficient ( $r$ ) with $p$ value $>0,05$.

Coefficient Of Determination $\left(R^{2}\right)$ OF 0,825 means that about $82,5 \%$ of leadership and motivational factors influencing job performance of employees Pekanbaru Universitas Lancang Kuning. Significant influence of leadership and motivational factors work against a university employee's work performance Pekanbaru Lancang Kuning Presumptuous. Shown from $F_{\text {hitung }}$ greater than the level $F_{\text {tabel }} \alpha=5 \%$. Of the research results show that $F_{\text {Countdown }}=0,0000$ and 6,992 $>\mathrm{t}_{\text {Countdown }}=1.660$. These results show that leadership factors have a relationship and the most dominant influence on employee perfomance Lancang Kuning Pekanbaru University
\end{abstract}

Keywords: Leadership, Motivation, and Employee Work Perfomance

Penelitian ini bertujuan untuk menganalisis dan meneliti Pengaruh Kepemimpinan dan Motivasi Kerja Terhadap Prestasi Kerja Karyawan Universitas Lancang Kuning Pekanbaru. Metode penelitian yang digunakan adalah deskriptif kuantitatif, sedangkan populasi dalam penelitian ini adalah karyawan Universitas Lancang Kuning yang berjumlah 70 orang. Teknik pengambilan sampel adalah stratified proportional random sampling. Untuk menentukan besarnya hubungan dan pengaruh suatu variabel bebas terhadap variabel terikat digunakan Model Analisis Regresi Linear Berganda. Sedangkan untuk menguji hipotesisnya menggunakan uji statistik. Hasil penelitian menunjukkan bahwa perhitungan secara statistik didapatkan Koefisien Korelasi Multiple (r) bernilai 0,825 dengan $p>0,05$.

Koefisien Determinasi $\left(R^{2}\right)$ sebesar 0,825 artinya sekitar 82,5\% faktor kepemimpinan dan motivasi kerja mempengaruhi prestasi kerja karyawan Universitasi Lancang Kuning Pekanbaru. Signifikan pengaruh faktor kepemimpinan dan motivasi kerja terhadap prestasi kerjs karyawan Universitasi Lancang Kuning Pekanbaru ditunjukkan dari nilai $F_{\text {hitung }}$ lebih besar daripada $F_{\text {tabel }}$ pada taraf $\alpha=5 \%$. Dari hasil penelitian menunjukkan bahwa $F_{\text {hitung }}=411,774$ lebih besar daripada $F_{\text {tabel }} 3,55$ dengan tingkat probabilitas $(p)=0,000$ lebih kecil dari 0,05. Dari angka-angka tersebut maka hipotesis nol ditolak berarti faktor kepemimpinan dan motivasi kerja berpengaruh terhadap prestasi kerja karyawan Universitas Lancang Kuning Pekanbaru. Uji secara parsial menunjukkan bahwa nilai koefisien determinasi parsial terbesar terdapat pada variabel kepemimpinan sebesar $60,9 \%$ dengan probabilitas 0,0000 dan $t_{\text {hitung }}=6,992>t_{\text {tabel }}=1.660$. Hasil ini menunjukkan bahwa faktor kepemimpinan mempunyai hubungan dan pengaruh yang paling dominan terhadap prestasi kerja karyawan Universitas Lancang Kuning Pekanbaru.

Kata Kunci : Kepemimpinan, Motivasi, dan Prestasi Kerja Karyawan 


\section{PENDAHULUAN}

Universitas Lancang Kuning merupakan univer-sitas swasta milik Pemerintah Daerah Provinsi Riau di bawah naungan Yayasan Raja Ali Haji. Universitas Lancang Kuning ini didirikan pada tanggal 1 Juni 1982, yang bertujuan untuk mewujudkan kesejahteraan umum dan mencerdaskan kehidupan bangsa serta meningkatkan kualitas sumber daya manusia, membentuk manusia Indonesia seutuhnya melalui pembinaan pendidikan tinggi berdasarkan Pancasila dan Undang-Undang Dasar 1945. Universitas Lancang Kuning turut berpartisipasi mewujud-kan pembangunan di bidang pendidikan, berpedoman pada Undang-Undang Nomor 2 Tahun 1989 --tentang Sistem Pendidikan Nasional dan Peraturan Pemerintah Nomor 60 Tahun 1999 tentang Pendidikan Tinggi.

Untuk melaksanakan tugas-tugas dalam rangka pencapaian tujuan perguruan tinggi, perlu disusun suatu perencanaan yang baik sebagai pedoman dalam melaksanakan tugas tentang apa yang dilakukan, kapan akan dilakukan, dan siapa yang melakukan. Tanpa adanya perencanaan yang baik mustahil akan membuahkan hasil yang lebih baik sesuai dengan yang diharapkan. Untuk itulah, pimpinan membentuk tim penyusun Rencana Strategi dan Pedoman Universitas Lancang Kuning.

Untuk kelangsungan hidup suatu Universitas, diperlukan kepemimpinan dan motivasi kerja terhadap prestasi kerja karyawan di lingkungannya. Kepemimpinan dan motivasi kerja yang tinggi, akan berdampak terhadap prestasi kerja karyawan. Sebab barometer keberhasilan suatu perguruan tinggi ditentukan oleh kepemimpinan dalam menghadapi iklim kompetisi yang semakin ketat pada era globalisasi sekarang ini.

Menurut hasil penilitan Rusman (2003:2) tentang "Pengaruh Gaya Kepemimpinan dan Kepuasan Kerja terhadap Motivasi Kerja Pegawai di Dinas Pendidikan Provinsi Jawa Barat bahwa kepemimpinan mempengaruhi motivasi kerja”. Mahyudin (2007:15) juga menemukan bahwa kepemimpinan dan motivasi kerja mempunyai pengaruh positif yang signifikan terhadap prestasi kerja atau kinerja pegawai. Mengelola manusia merupakan hal sangat penting dalam sebuah organisasi. Hal itu berhubungan erat dengan prestasi kerja manusia itu sendiri. Bagaimana mengelola manusia agar mereka menjadi manusia yang berprestasi tinggi dan juga bagaimana mengelola organisasi sebagai wadah dalam mencapai tujuan agar mempunyai prestasi kerja yang tinggi.

Universitas Lancang Kuning, dalam perkem-bangannya mempunyai kelemahan, yaitu peralatan dan fasilitas yang ada kurang tepat penggunaannya, instruk-si yang kurang jelas, tingkat kinerja yang diharapkan tidak wajar, otoritas formal yang ada tidak mencukupi, kurangnya rasa kerjasama antar individu, metode dan prosedur kerja didefinisikan dengan lemah, dan pembagian tugas yang kurang jelas. Hal ini terlihat bahwa setiap akhir tahun dilakukan rapat yang membahas mengenai per-tanggungjawaban tugas dan wewenang setiap fakultas, namun kenyataannya tugas dan wewenang yang diberikan tidak sepenuhnya dijalankan sebagaimana mestinya. Pelaporan pertanggung-jawaban yang diberikan hanya sekedar lepas tanggungjawab sehingga tidak memiliki nilai/kualitas yang berarti. Sedangkan kelebihannya terhadap karyawan, mem-berikan kesempatan kepada karyawan untuk melanjutkan studi, membawa karyawan untuk studi banding ke Universitas lain di Indonesia maupun luar negeri. Jadi, maju atau kurang majunya tergantung kepada sistem kepemiminan seseorang dalam mengelola suatu universitas.

Keberadaan sarana dan prasarana universitas yang memadai, namun prestasi kerja pegawainya rendah, maka sarana dan prasarana yang memadai tersebut tidak akan mampu memberikan kontribusi yang maksimal terhadap kerja karyawan. Sebaliknya jika prestasi kerja karyawan tinggi akan mampu mencapai tujuan yang telah ditetapkan di dalam rencana strategis Universitas Lancang Kuning.

Prestasi kerja karyawan dipengaruhi oleh beberapa faktor, baik yang berhubungan dengan tenaga kerja itu sendiri maupun terhadap faktor-faktor pendidikan, keterampilan, disiplin, sikap dan etika kerja, motivasi, gizi, dan kesehatan, tingkat penghasilan, jaminan sosial, lingkungan dan iklim kerja, teknologi, 
manajemen, kesempatan kerja dan kesempatan berprestasi (Tohardi, 2002:450). Seorang pemimpin dituntut mempunyai kemampuan dalam menggerakkan dan mempengaruhi bawahan tersebut, walaupun ia mampu merancang rencana strategi yang baik menunjukkan kurang berhasilnya seorang pemimpin.

Dengan demikian dapat dijelaskan bahwa kepemimpinan dan motivasi kerja dapat berpengaruh terhadap prestasi kerja karyawan. Berdasarkan hal tersebut, peneliti tertarik untuk meneliti tentang pengaruh kepemimpinan dan motivasi kerja terhadap prestasi kerja karyawan di Universitas Lancang Kuning Pekanbaru.

\section{METODE}

Berdasarkan pokok permasalahan yang diajukan, variabel yang digunakan dalam analisis adalah sebagai berikut:

1. Faktor kepemimpinan sebagai variabel bebas (variabel $\mathrm{X}_{1}$ ) dan faktor motivasi kerja sebagai variabel bebas (variabel $\mathrm{X}_{2}$ ).

2. Prestasi kerja karyawan sebagai variabel terikat (variabel Y).

Teknik Pengumpulan Data

Teknik sampel yang digunakan oleh peneliti adalah teknik Proportionate Stratified Random Sampling karena Universitas Lancang Kuning mempunyai karyawan dari latar belakang pendidikan yang berstrata atau tidak homogen dan berstrata secara proporsional, maka populasi karyawan itu berstrata. Karyawan Universitas Lancang Kuning berjumlah 70 orang.

Model Analisis yang digunakan

Teknik analisis statistik inferensial induktif yang akan digunakan adalah regresi linier berganda. Sudjana (2004:367) menjelaskan bahwa secara matematis analisis regresi linier berganda dapat dirumuskan seperti:

$$
\hat{Y}=a+b_{1} X_{1}+b_{2} X_{2}+e
$$

\section{HASIL DAN PEMBAHASAN}

\section{Uji Determinasi $\left(\mathbf{R}^{2}\right)$}

Selanjutnya menguji keterkaitan masing-masing variabel bebas terhadap variabel tidak bebas dengan menggunakan uji $\mathrm{R}^{2}$ (determinasi parsial) dengan bantuan program SPSS 15 sebesar 0,825.

Uji F

Untuk membuktikan kebenaran hipotesis secara bersama-sama digunakan uji $\mathrm{F}$, yaitu untuk menguji keberartian koefisien regresi berganda dan membandingkan $F_{\text {hitung }}$ dengan $F_{\text {tabel }}$ pada $\alpha=0,05$, jika:

1. $\mathrm{F}_{\text {hitung }} \geq \mathrm{F}_{\text {tabel }}$ maka Ho ditolak dan $\mathrm{H} 1$ diterima

Artinya model regresi berhasil menerangkan pengaruh variabel bebas $\left(X_{1}\right.$ dan $\left.X_{2}\right)$ secara bersama-sama terhadap variabel tidak bebas (Y).

2. $\mathrm{F}_{\text {hitung }} \leq \mathrm{F}_{\text {tabel }}$ maka Ho diterima dan $\mathrm{H} 1$ ditolak

Artinya model regresi tidak berhasil menerangkan pengaruh variabel bebas $\left(\mathrm{X}_{1}\right.$ dan $\left.\mathrm{X}_{2}\right)$ secara bersama-sama terhadap variabel tidak bebas (Y).

Berdasarkan hasil uji hipotesis pada tabel 5 diatas terlihat bahwa $\mathrm{F}_{\text {hitung }}$ lebih besar daripada $\mathrm{F}_{\text {tabel }}$ yaitu 411,774 > 3,55, artinya terbukti model regresi yang dipakai berhasil menerangkan pengaruh variabel bebas $\left(\mathrm{X}_{1}\right.$ dan $\left.\mathrm{X}_{2}\right)$ secara bersama-sama secara signifikan terhadap variabel tidak bebas $(\mathrm{Y})$. Dan 
determinasi $\left(\mathrm{R}^{2}\right)$ sebesar $82,5 \%$, sedangkan sisanya $(100 \%-82,5 \%)=17,5 \%$ dipengaruhi oleh sebab lain diluar model ini.

Tabel 5 diatas dan dari kedua variabel bebas yang dimasukkan dalam model regresi, variabel kepemimpinan dan motivasi kerja berpengaruh signifikan pada $\alpha=0,05$. Hal ini dapat disimpulkan bahwa variabel prestasi kerja karyawan Universitas Lancang Kuning Pekanbaru dipengaruhi oleh variabel kepemimpinan dan motivasi kerja dengan persamaan matematis sebagai berikut:

$$
\begin{aligned}
& \hat{\mathbf{Y}}=\mathbf{a}+\mathbf{b}_{1} \mathbf{X}_{1}+\mathbf{b}_{2} \mathbf{X}_{2}+\mathbf{e}
\end{aligned}
$$

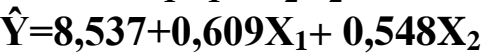

Konstanta sebesar 8,537 menyatakan bahwa jika variabel bebas dianggap konstan, maka rata-rata prestasi kerja karyawan Universitas Lancang Kuning Pekanbaru sebesar 8,537\%. Koefisien regresi variabel kepemimpinan 0,609 menyatakan bahwa setiap penambahan 1 usaha meningkatkan kepemimpinan akan meningkatkan prestasi kerja karyawan sebesar 0,609\% dan koefisien regresi variabel motivasi kerja sebesar 0,548 menyatakan bahwa setiap penambahan 1 motivasi keja akan meningkatkan prestasi kerja sebesar $0,548 \%$.

\section{Kepemimpinan Berpengaruh Secara Signifikan Terhadap Prestasi Kerja}

Faktor kepemimpinan dalam penelitian ini terbukti secara parsial mampu memberikan kontribusi yang signifikan dalam mempengaruhi prestasi kerja. Dalam hal ini faktor-faktor kepemimpinan dapat memberikan pengaruh yang signifikan terhadap prestasi kerja. Dengan dukungan kepemimpinan maka prestasi kerja karyawan Universitas Lancang Kuning Pekanbaru dapat meningkat. Dengan kata lain apabila variabel kepemimpinan meningkat maka prestasi kerja karyawan juga akan meningkat dan sebaliknya jika kepemimpinan menurun maka prestasi kerja akan menurun.

Namun demikian kontribusi dari variabel kepemimpinan terhadap prestasi kerja yang mencapai 60,9\% dapat diartikan juga bahwa dengan kriteria-kriteria tugas yang telah diberikan dalam bentuk pelaksanaan tugas sudah dilaksanakan dengan maksimal akan tetapi hasil yang dicapai tentunya tergantung daripada komitmen institusi Universitas Lancang Kuning Pekanbaru dalam memberikan umpan balik kepada karyawannya. Bentuk-bentuk kepemimpinan yang perlu diberikan seperti penghargaan, perhatian, kesempatan karier dan sebagainya. Namun demikian bentuk-bentuk kepemimpinan ini tentunya sangat tergantung dari model kepemimpinan yang ada saat ini yang menjadi bagian dari karyawan.

\section{Motivasi Kerja Berpengaruh Secara Signifikan Terhadap Prestasi Kerja}

Variabel motivasi kerja dalam penelitian ini terbukti mampu memberikan kontribusi yang positif dan signifikan dalam mempengaruhi prestasi kerja. Hal ini berarti faktor-faktor yang berhubungan dengan motivasi kerja telah membentuk motivasi kerja yang baik karyawan Universitas Lancang Kuning Pekanbaru. Pengaruh variabel motivasi kerja terhadap prestasi kerja searah, artinya peningkatan terhadap motivasi kerja akan berdampak kepada peningkatan prestasi kerja dan sebaliknya jika motivasi kerja menurun maka prestasi kerja akan mengalami penurunan. Kondisi yang demikian sebaiknya dapat diperhatikan sehingga prestasi kerja karyawan dapat dipertahankan dan bila perlu ditingkatkan.

Hubungan dan pengaruh yang signifikan ini memberi arti bahwa tingkat motivasi kerja meningkat maka prestasi kerja karyawan juga cenderung meningkat pula, demikian sebaliknya bila motivasi kerja menurun maka terhadap prestasi kerja karyawan Universitas Lancang Kuning Pekanbaru cenderung menurun. 


\section{Kepemimpinan dan Motivasi Kerja Berpengaruh Secara Signifikan Terhadap Prestasi Kerja}

Kepemimpinan dan motivasi kerja berdasarkan hasil penelitian telah terbukti secara signifikan mempengaruhi prestasi kerja karyawan Universitas Lancang Kuning Pekanbaru. Secara keseluruhan kedua variabel tersebut mempengaruhi prestasi kerja sebesar $82,5 \%$. Hal ini berarti $17,5 \%$ bahwa prestasi kerja karyawan Universitas Lancang Kuning Pekanbaru. Dipengaruhi oleh variabel lain diluar penelitian ini. berdasarkan teori yang telah dikemukakan bahwa faktor kepemimpinan dan motivasi kerja berpengaruh terhadap prestasi kerja serta hipotesis yang telah diajukan dapat diterima.

\section{KESIMPULAN}

Berdasarkan penelitian yang dilakukan pada karyawan Universitas Lancang Kuning Pekanbaru dapat disimpulkan bahwa Faktor kepemimpinan dan motivasi kerja secara parsial berpengaruh signifikan terhadap prestasi kerja karyawan Universitas Lancang Kuning Pekanbaru dan mempunyai pengaruh positif atau searah terhadap prestasi kerja. Kondisi ini menunjukkan bahwa:

1. Jika kepemimpinan meningkat maka prestasi kerja karyawan juga meningkat dan sebaliknya. Peningkatan kepemimpinan dalam perhatian dan penghargaan yang diberikan pimpinan kepada karyawannya.

2. Jika motivasi kerja meningkat maka prestasi kerja juga akan meningkat. Peningkatan motivasi kerja dalam bentuk gairah kerja, kompensasi yang sesuai dan sebagainya.

3. Secara simultan atau secara bersama-sama diperoleh hasil bahwa faktor kepemimpinan dan motivasi kerja mempunyai pengaruh yang signifikan terhadap prestasi kerja karyawan Universitas Lancang Kuning Pekanbaru.Dalam penelitian variabel bebas yang secara parsial yang paling dominan berpengaruh signifikan terhadap prestasi kerja karyawan Universitas Lancang Kuning Pekanbaru adalah faktor kepemimpinan.

\section{SARAN}

Menindak lanjuti kesimpulan dalam penelitian ini, maka dapat dikemukakan beberapa rekomendasi sekaligus saran-saran sebagai berikut:

1. Faktor kepemimpinan berdasarkan hasil penelitian mempunyai pengaruh yang signifikan terhadap prestasi kerja karyawan. Kepemimpinan hendaknya menjadi perhatian yang serius bagi institusi Universitas Lancang Kuning Pekanbaru, hal ini dapat dilakukan dengan meningkatkan perhatian dan penghargaan kepada karyawan serta hal lain yang dapat memberikan kontribusi dalam rangka peningkatan prestasi kerja.

2. Faktor motivasi kerja berdasarkan hasil penelitian mempunyai pengaruh yang signifikan terhadap prestasi kerja karyawan Universitas Lancang Kuning Pekanbaru. Motivasi Kerja hendaknya dapat diperhatikan untuk dapat menjaga konsistensi karyawan dimasa yang akan datang. Pemberian kompensasi, insentif, tunjangan serta perlindungan bagi pegawai juga akan memberikan motivasi kerja bagi karyawan sehingga dalam melakukan aktifitas dalam bekerja akan semakin baik.

3. Dalam hal pengembangan sumber daya manusia hendaknya pihak Universitas Lancang Kuning Pekanbaru memperhatikan karyawan sebagai individu secara utuh bukan sematamata sebagai faktor produksi. Tidak hanya melalui keterampilan dan kepandaian saja, tetapi juga kepemimpinan dan motivasi kerja perlu mendapat perhatian yang serius, sebab faktorfaktor ini menentukan tercapainya peningkatan prestasi dari karyawan itu sendiri 


\section{DAFTAR PUSTAKA}

[1]. A., Djumino, Wahyudin, M, 2002, Pengaruh Kepemimpinan dan Motivasi Terhadap Kinerja Karyawan, Tesis, Tidak dipublikasikan

[2]. Anoraga, Panji, 2002, Perilaku Organisasi, Jakarta: Pustaka Jaya.

[3]. Arep, Ishak, dkk, 2004, Manajemen Motivasi, Jakarta: Gramedia

[4]. Asril, 2006, Pengaruh Gaya kepemimpinan, Program Pendidikan dan Pelatihan serta Motivasi Kerja terhadap Kinerja Pegawai di Lingkungan Dinas Kimpraswil Kabupaten pelalawan, Jurnal Tepak Manajerial, 05 Juli 2006 Program MM Universitas Riau Pekanbaru

[5]. Badari, 1999, Hubungan motivasi berprestasi dan disiplin kerja dengan prestasi kerja pegawai Departemen Pendidikan dan Kebudayaan Kecamatan se-Kabupaten Lampung Utara, Padang: Jurnal Forum Pendidikan Universitas Negeri Padang.

[6]. Danim, Sudarwan, 2003, Motivasi Kepemimpinan dan efektivitas Kelompok, Jakarta: Rineka Cipta.

[7]. Darman Dapersal, 2006, Kontribusi Motivasi Kerja dan Persepsi tentang Sistem Pengahargaan terhadap Prestasi Kerja Pegawai Politeknik Negeri Padang, (Tesis: tidak dipublikasikan), Padang: Program Pascasarjana UNP.

[8]. Dessler, Gary, 1997, Manajemen Sumber Daya Manusia Human Resource Management 7e, Jakarta: Prenhallindo.

[9]. Dewi, Puspa, 2006, Pengaruh Kemampuan dan Motivasi terhadap Kinerja Karyawan pada PT. Bank Rakyat Indonesia CabangRengat, Jurnal Tepak Manajerial, 05 Juli 2006 Program MM Universitas Riau Pekanbaru.

[10]. Dewita, Erma, 2006, Hubungan Motivasi dan Disiplin Kerja dengan Prestasi Kerja Karyawan di Universitas Andalas Padang, Padang: Jurnal Forum Pendidikan Universitas Negeri Padang.

[11]. Dharma, Surya, 2005, Manajemen Kinerja Falsafah Teori dan Penerapannya, Pustaka Pelajar.

[12]. Gusanto, A. Y, 2006, Pengaruh Motivasi dan Kepemimpinan terhadap Kinerja Pegawai pada PT. Adhi Karya (Persero) Tbk Cabang II Riau-Sumbar, Pekanbaru: Jurnal Tepak Manajerial Magister Manajemen UNRI.

[13]. Hani Handoko, Hani, 2000, Manajemen, Yogyakarta: BPFE UGM

[14]. Hasibuan, Melayu, S.P, 2001, Manajemen Sumber Daya Manusia; Dasar dan Kunci Keberhasilan. Jakarta: Mas Agung.

[15]. Heidjrachman, dkk, 2002, Manajemen Personalia Edisi 4, Jakarta: BPFE UI. 
[16]. Ilyas, Yaslis, 2006, Kiat Sukses Tim Kerja, Jakarta: Gramedia.

[17]. Istijanto, 2006, Riset Sumber Daya Manusia Cara Praktis Mendeteksi Dimensi-Dimensi Kerja Karyawan. Jakarta: Gramedia.

[18]. Isyandi, B, 2004, Manajemen Sumber Daya Manusia, UNRI Press.

[19]. Makmun, Syamsuddin, Abin, 2006, Psikologi Kependidikan, Perangkat Sistem Pengajaran Modul, Bandung: Remaja Rosdakarya.

[20]. Mangkunegara, A.A, Anwar Prabu, 2005, Evaluasi Kinerja SDM. Bandung: Aditama.

[21]. Mangkunegara, Prabu, Anwar, 2004, Manejemen Sumber Daya Manusia Perusahaan, Bandung: Rosdakarya.

[22]. Manullang, M, 2002, Manajemen Personalia, Jakarta: Ghalia Indonesia.

[23]. Panggabean, Sangkan, 2006, Pengaruh Kepemimpinan, Kecerdasan Emosional, dan Motivasi Berprestasi terhadap Kinerja Pegawai Kanwil Departemen Hukum dan HAM Sumbar, Padang: Jurnal Forum Pendidikan Universitas Negeri Padang.

[24]. Prawironegoro, Darsono, 2006, Budaya Organisasi Kajian tentang Media, Budaya, Ekonomi, Sosial dan Politik, Jakarta: Diadit Media.

[25]. Purwanto, Ngalim, 2003, Psikologi Pendidikan, Bandung: Rosdakarya.

[26]. Riduwan, 2004, Metode dan Teknik Menyusun Tesis, Bandung: Alfabeta.

[27]. Rivai, Veithzal, 2004, Kiat memimpin dalam abad 21, Jakarta: Murai kencana 